\title{
Eight years of tracking and treating severe malaria in Europe
}

Florian Kurth

Michel Develoux

Matthieu Mechain

Denis Malvy

Jan Clerinx

Spinello Antinori

Ida E. Gjørup

Joaquím Gascon

Kristine Mørch

Emanuele Nicastri

Michael Ramharter

Alessandro Bartoloni

Leo Visser

Thierry Rolling

Philipp Zanger

Guido Calleri

Joaquín Salas-Coronas

Henrik Nielsen

Gudrun Just-Nübling

Andreas Neumayr

Anna Hachfeld

Matthias L. Schmid

Pietro Antonini

Tilman Lingscheid

Peter Kern

Annette Kapaun

José Saraiva da Cunha

Peter Pongratz

Antoni Soriano-Arandes

Mirjam Schunk

Norbert Suttorp

Christoph Hatz

Thomas Zoller 


\section{Video Abstract}

Keywords: malaria, severe malaria, clinical study, Europe, quinine, artesunate, plasmodium falciparum, European Network for Tropical Medicine and Travel Health, TropNet, travel risk, observational study, travelers' health, anti-malarial chemoprophylaxis, hyperparasitemia, adverse drug reaction, postartemisinin delayed hemolysis, malaria prevention, tropical medicine, semi-immunity, acquired partial immunity

Posted Date: September 20th, 2019

DOI: https://doi.org/10.21203/rs.2.15116/v1

License: (c) (i) This work is licensed under a Creative Commons Attribution 4.0 International License. Read Full License 


\section{Abstract}

Even though Europe is far from malarial hot spots, doctors there still have to treat travelers who contract the disease while on holiday or business trips. And because Europeans aren't exposed to malaria on a regular basis, if they do become infected with the parasites, they're more likely to develop a severe case. To keep tabs on how malaria is treated across 12 European countries, the European Network for Tropical Medicine and Travel Health, or TropNet, regularly collects data. Now, a report on all of its severe malaria cases between 2006 and 2014 offers an unprecedented look at malaria treatment across the continent. Over the 8-year period, epidemiologists counted 185 cases of severe malaria in the network, primarily following visits to West or central Africa. The outcome was good for the vast majority of patients: 98.4 percent survived. But there was a lot of variation in how people were treated. Hospitals used 56 different drug combinations. In the beginning of the study period, quinine was the most popular drug, but artesunate - the recommended option - surpassed it by 2014. As Europe's demographics have changed, so too has its malaria profile. In the past, nearly all cases of malaria were seen in tourists or business travelers. But now, 30 percent of patients are immigrants who catch the disease when visiting friends and family in their former homelands. This is an important finding, as it suggests that many immigrants are not aware that any acquired immunity protecting them from severe malaria wanes the longer they live outside endemic areas. The results suggest that Europeans would benefit from evidence-based guidelines to make treatment more consistent. Although artesunate is not yet licensed for treatment in Europe, it is the more effective option for severe malaria, and its increased use may be contributing to high survival rates. Patients treated with artesunate, however, should be carefully followed, as late haemolytic reactions occur in one out of four people. Finally, only 10 percent of patients had taken drugs to prevent malaria prior to their trips and few of those took all tablets as prescribed. More people may be able to avoid complicated cases of malaria by properly taking prophylactic drugs when traveling. 